\title{
Resource Nationalism Specter Hovers Over The Oil Industry: The Transnational Corporate Strategy To Tackle Resource Nationalism Risks
}

Professor Sajjad M. Jasimuddin, Kedge Business School, France

Professor A F M (Munir) Maniruzzaman, Portsmouth University, UK

\begin{abstract}
Resource nationalism is building momentum across oil-endowed countries. Transnational corporations (TNCs) have to effectively address the emerging scenarios that are caused by the resurgence in resource nationalism. This is clearly a diserable focus that has received much attention in the literature on government-business relations ever since the oil nationalization of the 1970s. But there is limited literature that provides a synthesized view on the transnational oil companies' (TNOC) strategies to tackle resource nationalism risk; this leaves a gap in the literature where the paper aims to contribute. The paper explores the exclusive literature on resource nationalism and the activities of TNOCs, and from this literature engages in conceptual development. The paper focuses on the notion of resource nationalism and its implications on TNOCs' activities in host states. This paper provides policy guidelines, suggesting the ways in which the major TNOCs can respond with robust responsible and sustainable programs to the resource nationalism in the global oil industry.
\end{abstract}

Keywords: Resource Nationalism, Transnational Corporations, National Oil Companies, Oil Price Boom

\section{INTRODUCTION}

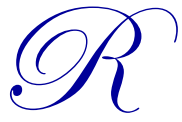

esource nationalism in the petroleum industry is not a new phenomenon, which has emerged in the second half of the 20th century, the era of decolonization (Sarsenbayev, 2011). The oil-endowed countries are making efforts to consolidate ownership over strategically important oil resources (Buchanan and Anwar, 2009; Kretzschmar et al., 2010). Stevens (2008) argues that resource nationalism has proved to be a cyclical phenomenon. Recently such a move appears to be growing in countries from Australia to Zambia and many in between. The 2000s and early 2010s see the tendency of the petroleum-rich countries to bring significant oil ownership under state control from transnational oil companies (TNOCs).

The fact the fresh rise of resource nationalism has been found sparked by oil price boom caused by various geopolitical and market condition, which has led to a renewed discussion among researchers and policy makers. A recent Ernst and Young's (E\&Y, 2011) report support this, arguing that the increasing spectre of resource nationalism as the number-one risk facing mining industries. Resource nationalism is treated as a risk factor for TNOCs, creating disputes between them and their host governments, which sometimes creates distance in their relationship.

Although the existing literature on resource nationalism is extensive, the issues surrounding TNOCs' strategies to deal such a risk is limited. The paper intends to fill that gap. The aim of this paper is to discuss the rationale behind resource nationalism along with the possible means at the TNOCs' disposal to minimize the potential damage that may cause due to resource nationalism. The paper concentrates on resource nationalism in the petroleum industry from the perspective of TNOCs. There are several routes - legal, political, and social - which seem to help tackle resource nationalism risks. In this regard, the notion can better be understood in the "cause and effect" scenario. 
The paper is organized as follows. Section 2 discusses the political economy of resource nationalism. The main causes of resource nationalism in the oil industry are identified in Section 3. Section 4 looks at the strong presence of national oil companies (NOCs), which also triggers the fresh wave of resource nationalism. The implications of resource nationalism on TNOCs are elaborated in Section 5. Section 6 addresses the strategies that major TNOCs can employ to tackle the new wave of resource nationalism. Some policy conclusions are presented in the final section.

\section{THE POLITICAL ECONOMY OF RESOURCE NATIONALISM}

The term "resource nationalism" typically refers to a policy used by a resource-rich country to ensure maximum revenues from its natural resources. Resource nationalism policy is believed to be initiated by an oil-producing country to guarantee more equitable sharing of the profits from its oil resources. The majority of the oil-rich nations are very much nationalist in their petroleum sector. Moreover, resource nationalists intend to make sure that their oil reserves are not depleted too quickly for the long-run benefit of consumers (Mares, 2011).

Some researchers (e.g., Stanislaw, 2008; Click and Weiner, 2010) argue that resource nationalism is used to describe the host government policy to assert greater state control over its natural resources located on its territory, mostly from TNOCs for strategic and economic reasons. Resource nationalism has a distinctly anti-West character, because anticolonial experience of oil-rich countries makes them think to losing control over their natural resources (Sikri, 2010). A key issue concerns how 'resource nationalism' is defined (Stevens, 2008) as there is no single comprehensive definition of resource nationalism (Sarsenbayev, 2011).

For example, Stanislaw (2008) contend that resource nationalism broadly refers to state control or dominance of energy resources, and the resultant potential to use this power for political and economic purposes, including relationships with the major TNOCs. Parallel to this, Domjan and Stone (2010) define it as a policy of oil-endowed countries aimed at enhancing governments' consolidation ownership over oil resources, and increasing their share from oil revenue earned by TNOCs.

Resource nationalism has witnessed itself in different forms of events over the years. The oil-rich nations' government can move either to harden fiscal and contract terms for TNOCs, or to restrict access to their reserves. It actually ranges from imposing windfall profit taxes (as has been the case in the UK) to expropriating OICs (as has been the case of Conoco-Phillips and ExxonMobil in Venezuela and Bolivia). Resonating with this, Guriev et al. (2008) state that resource nationalism is taking from a brutal form to a soft form. A host nation takes a soft form, when host governments' actions are based on fiscal or environmental regulations. On the other hand, a host nation takes a brutal form, when granted subsoil use rights are revoked unilaterally or TNOCs' assets are expropriated without any compensation. For example, Ecuador used troops to take over Occidental Petroleum's holdings in 2006, and then turned them over to its NOC Petroecuador (Click and Weiner, 2010).

More than 25 countries have increased or announced intentions to increase their government take of profits via taxes/royalties from 2003 to 2008. Tax or royalty increases are not the only manifestations of resource nationalism in the oil sector. The oil-rich nations believe that many of the contracts concluded with TNOC in 1990s are perceived as unfair and damaging to national interests (Sarsenbayev, 2011). In line with this, the host governments attempt to renegotiate the terms of contracts along with creating pressure on the OICs to increase NOCs' participation in projects. As Partlett (2010) reports that oil-rich countries particularly from Latin America and Africa have unilaterally either enacted laws to increase state involvement in their oil industry or renegotiated contracts to impose new terms that have increased the host government's take of profits. Very recently, Argentina's president Cristina Fernandez announced to renationalize YPF its biggest oil company, ousting the Spanish group Repsol as majority shareholder, which would be the biggest renationalization in the natural resources industry since the Russian government took control of Yukus in the early 2000s (Webber and Johnson, 2012).

\section{THE RATIONALE BEHIND THE RECENT WAVE OF RESOURCE NATIONALISM}

Today the world is experiencing a new wave of resource nationalism (Sarsenbayev, 2011) http://jwelb.oxfordjournals.org/content/4/4/369.full - aff-1\#aff-1. What causes resource nationalism on the global oil industry is an important question to address in order to understand the phenomenon. The operation of the geopolitics 
of oil represents the greatest global competition for natural resources (Sikri, 2010). There are many and varied reasons for the resource nationalism in the petroleum sector. Resonating with this, Hughes and Kreyling (2010), for example, contend that oil price volatility underpinned by demand growth. These factors are mentioned, in turn, below.

The key factor that drives resource nationalism in the oil industry is exorbitantly high oil prices. A recent article in The Economist (2006) questioned whether high oil prices stimulate "resource nationalism." Since 2002, the price of oil per barrel on the world market has increased from a low of $\$ 17.10$ per barrel to a record $\$ 146$ per barrel in July 2008 (Maloney, 2008). In the oil industry, the major cause of resource nationalism is the windfall generated particularly as oil prices became high in 2007-2008 (Buchanan and Anwar, 2009). Since TNOCs experience record profits, the host governments attempt to levy the windfall tax. It is noticed that oil-rich nations have increased tax so as to seek a larger share of the super profits generated due to the oil price boom. Parallel to this, Partlett (2010) puts it: It's a cyclical occurrence linked to rising commodity prices, which triggered some host governments to force unilateral restructuring of contracts and concessions, or even a change in ownership that flips the TNOCs from a majority to minority position.

There is no doubt that oil price boom leads to higher profits. However, the surge of resource nationalism that it is found today is about more than just due to high oil price. Reflecting this view, Ward (2009) states that in reality resource nationalism is driven by a far more complex and varied set of factors than price alone. Other underlying factors that influence the resource nationalism are discussed below.

Several studeis (e.g., Stevens, 2008; Muniruzzaman, 2009) show that resource nationalism is associated with 'obsolescing bargain.' The fact that bargaining power seems to shift from TNOCs to oil-rich nation after most investment costs have been sunk, and a development phase is about to complete. At this stage, the host government has a tendency to increase its fiscal take by changing the terms of the original contract. In his classical book Sovereignty at Bay, Harvard economist Raymond Vernon (1971) described this phenomenon as 'obsolescing bargain.'

Hostile political environment in many oil-exporting states is also identified as a reason for the increased resource nationalism trend (Vivoda, 2009). There is a political perspective that encourages host governments to adapt to a resource nationalism policy. Country sovereignty plays a vital role and becomes one of the major driving forces, especially after a decolonization period (Domjan and Stone, 2010). Resonating with this, Click and Weiner (2010) state that at the heart of resource nationalism is a government's intervention in its country's oil resources to protect or enhance its national sovereignty. Recently there is a rise in the invocation of the principle of 'permanent sovereignty' over natural resources (Ward, 2009). In various geo-political situations, the nation's sovereign authority tended to assert over the upstream and downstream activities of TNOCs in the oil sector (Maniruzzaman, 2009). Under these changing circumstances, (e.g., oil price hikes), governments take unilateral action in response to nationalistic sentiments and political pressure to increase its revenues.

Furthermore, the increasing demand for oil is another determinant that also causes resource nationalism. Both the industrialized nations and emerging economies have become unprecedentedly dependent on oil not just for their continued prosperity but also for their very survival (Sikri, 2010). The International Energy Agency's 2008 World Energy Outlook 'reference scenario to 2030 suggests that world primary energy demand will grow by $45 \%$ between 2006-2030, with China and India accounting for half of incremental energy demand (Ward, 2009).

According to EIA (2010), Global petroleum consumption increased 36\%, nearly 23 million barrels per day between 1980 and 2010. Together, the Middle Eastern, Central and South American, and African share of total global oil demand grew from $11 \%$ in 1980 to $20 \%$ in 2010. Moreover, EIA's (2010) statistics also shows that Asia surpassed North America as the largest petroleum-consuming region in 2008. Corresponding to this, Asian demand surged nearly 15 million barrels per day during the period, an increase of 146\%, while North America's petroleum consumption increased $16 \%$. The global demand for oil is skyrocketing largely because of rising consumption in the emerging economies (e.g., China, India). Hence, these countries need to secure access to scarce oil resources. They have vast populations, resulting recently to climb the economic ladder (Stanislaw, 2008). For example, China is the rising global industrial powerhouse, which is the world's second-largest economy after the US. As demand for oil increases, driven by relentless growth in the emerging countries, competition for oil resources will keep growing. 


\section{THE ROLE OF NOCS TO CONTROL OIL RESOURCES}

NOCs appear to be playing a leading role in initiating resource nationalism in the oil sector. For example, the Venezuela government has taken extreme measures to encourage its NOC - Petróleos de Venezuela SA (PDVSA) to directly involve in TNOCs' projects. However, it would be a mistake to conclude that NOCs is coming only from the oil-endowed nations. Interesting, the NOCs of oil-importing countries like China, India and Japan are active in the sector, and have emerged as a big threat for TNOCs. These NOCs are going abroad in search of long-term supply contracts to feed growing demand for oil and gas (Bremmer, 2008). Demand growth has led emerging economies, including China and India, to increase state support for national-flag companies - for example, the Chinese National Petroleum Corporation (CPCN) - so as to increase the state's energy self-sufficiency.

NOCs, irrespective of their origin, have made energy investments worldwide. Most specifically, the seven sisters Saudi Aramco, Gazprom (Russia), the CNPC, the National Iranian Oil Company (NTNOC), PDVSA, Venezuela, Petrobras (Brazil), and Petronas (Malaysia) are the largest NOCs in the world today. As a result, the percentage of the oil managed and controlled by NOCs is exponentially increasing. Around $80 \%$ of reserves of oil are located in the countries where NOCs have direct or indirect control and privileged access to them (Hartley et al., 2007; Stanislaw, 2008; Kalyuzhnova and Nygaard, 2009). The fact that there has been a growing role for NOCs, both from producer states like Brazil and consumer states like China. The existence of NOCs encourages oil-rich countries to take bold move to resource nationalism (Kalyuzhnova and Nygaard, 2009).

\section{IMPLICATIONS ON OIL INDUSTRY AND TNOCS}

What effect the current resource nationalism produces on the petroleum sector and TNOCs is essential to explore so as to advance our understanding of the phenomenon. This section explores the consequences of resource nationalism. The oil industry accounts for the largest single component of international trade (Weiner, 2005), which is one of the largest industries for cross-border investment (Click and Weiner, 2010). TNOCs have resumed a dominant role in the petroleum industry (van der Linde, 2000). The global oil industry was once ruled by the so-called 'super major TNOCs: Standard Oil of New Jersey, Royal Dutch Shell, Anglo-Persian Oil Company, Standard Oil of New York, Standard Oil of California, Gulf Oil and Texaco. The fact is that access of OICs to world oil and gas resources has decreased over time. Presently, the OICs have limited access to worldwide oil and gas resources. Figure 1 shows TNOCs' access to world oil and gas reserves over time. 
Figure 1. TNOCs' Access to World Oil and Gas Reserves Over Time

\section{Constrained Worldwide Oil \& Gas Reserve Access: Limited IOC Access Now than in 1970s}

\section{0}

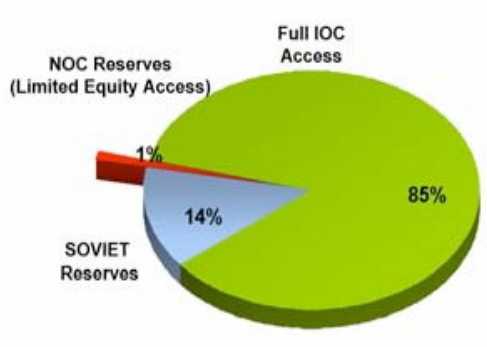

1998

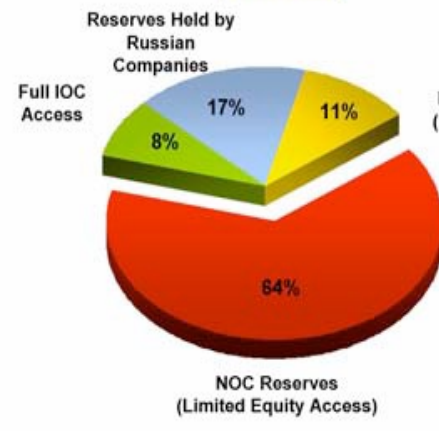

1980

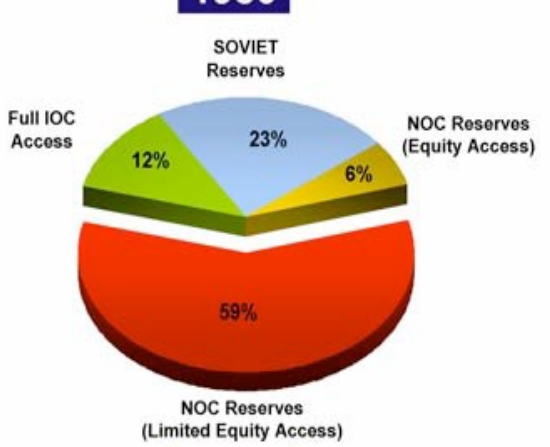

2005

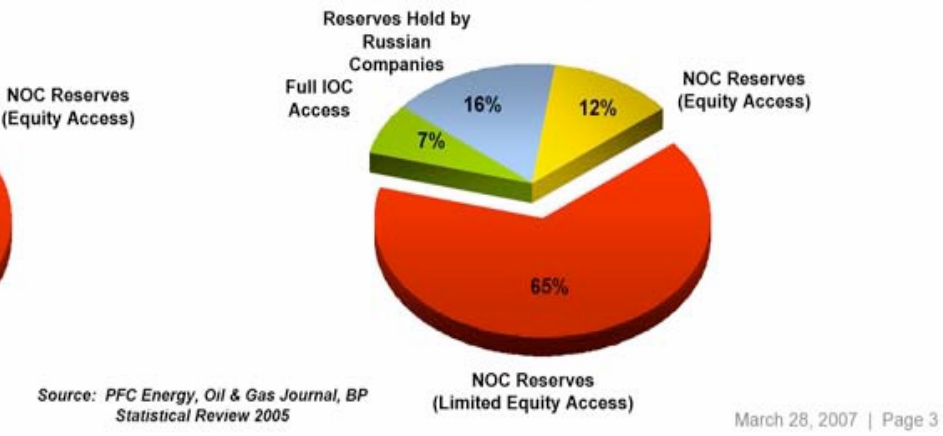

Source: PCF Energy (2007)

In June 2007, the Venezuelan government has forced ConocoPhillips and ExxonMobil to abandon their multi-billion dollar investments. At the same time, Total and Statoil were asked to reduce their holdings to allow PDVSA to enlarge its share. But today's largest TNOCs, led by ExxonMobil, Chevron, British Petroleum and Royal Dutch Shell, produce just $10 \%$ of the world's oil and gas and hold about $3 \%$ of its reserves (Bremmer, 2008). The largest energy companies in the world today are NOCs. In fact, three-quarters of the world's crude-oil reserves are now owned by NOCs (Jarfe and Soligo, 2007).

Since the oil sector is thought to be highly profitable, host governments are targeting the sector to gain larger share of the profits. As a result, the recent wave of resource nationalism is emerging as the biggest threat facing the oil sector. Resource nationalism is proving to be a potential risk for TNOCs as governments in a variety of resource-rich countries are examining options to gain a greater share of the windfall profits generating from high oil prices. Current high oil prices have made resource nationalism more attractive to oil-rich countries around the world.

Due to the recent wave of resource nationalism, TNOCs face significant challenges, particularly a high level of uncertainty that scares away them. There are constant pressures from the oil-rich nations on TNOCs. Without doubt, high oil prices have helped major TNOCs in generating unprecedented profits. At the same time, high oil prices have fuelled the resurgence of resource nationalism, which severely limits TNOCs' operations in oil-endowed countries. Hence, oil price boom is a sword that cuts both ways. Most of the oil-endowed nations' governments have either increased or announced an intention to increase the take of the state from the oil sector. 
It is observed that their presence in an oil-endowed country depend at the host government's support. For example, the TNOCs like Shell, TNK-BP and Exxon find themselves at the mercy of political machinations in Russia (Bremmer and Johnston, 2009). The TNOCs don't have the upper hand in the relationships with host governments when oil price increases.

Moreover, NOCs, such as Saudi Aramco, the National Iranian Oil Company, PDVSA, Petrobras (Brazil), and Petronas (Malaysia), are established by oil-rich countries. There are oil importing NOCs such as the CNPC which are found very active and powerful in the oil industry. NOCs originated from oil rich nations and oil importing countries are emerging big threat for TNOCs. (Ward 2009; Vivoda, 2009; Bremmer, 2008; Herberg, 2011). For instance, TNOCs are facing the growing competition from the NOCs originated in the oil-rich nations which tend to control strategic resources and downstream markets as competitors (Herberg, 2011). NOCs, which fully backed by their governments' support, do potentially threaten the capability of Western TNOCs to compete in the oil industry. Recently, there is an increasing competition from oil extraction service provider companies.

Moreover, most NOCs originated from oil importing countries now have international activities. For example, both Chinese and Indian NOCs have made energy investments worldwide, including in Sudan and Iran (Ward (2009). The emerging trend of downstream and upstream internationalization of NOCs is particularly creating severe pressure on a TNOC. As McCracken (as cited in Muniruzzaman, 2009) put it

"Squeezed between the twin pressures of resource nationalism and the state-sponsored NOCs of energyhungry nations, TNOCs are being locked out of the easier-to-exploit resources because NOCs can do it themselves, particularly with services companies that have technology for hire."

Recent developments in the petroleum industry have had a negative effect on the profitability of TNOCs. Host government intervention in this industry worldwide is causing increasing uncertainty among TNOCs. Most specifically, the rising risks of resource nationalism have an impact on TNOCs' performance and its share values. TNOCs complain that resource nationalism cuts into their profits and deters future investment by adding an unnecessary element of political uncertainty. In the current scenario, the TNOC have been unsuccessful in bargaining with their major actors, such as government of oil-rich countries and oil importing countries, and NOCs.

It is crucial for TNOCs to take these factors into account so that they could respond accordingly to avoid government's resource nationalism policy. With this aim in mind, the ways in which the major TNOCs may respond to the resource nationalism in the oil industry are discussed in turn.

\section{MEASURES TO RESPOND TO THE RESOURCE NATIONALISM}

Resource nationalism may lead to various disputes between the oil rich nation and TNOCs. However, resource nationalism risk can be managed and avoided through legal, political and social means. This section discusses mechanisms from the legal, political and social perspectives that may be used by major TNOCs to tackle the resource nationalism challenge. Drawing on the existing literature and observing the global activities, the paper suggests the strategies that major TNOCs may adopt to deal with systemic changes, particularly resource nationalism, in the oil industry.

Although resource nationalism can be seen as a legitimate right for sovereign nations, the host government's actions against or interferences with TNOC's interests could be tantamount to a breach of contractual rights. Such disputes are very common in the recent resource nationalism as have been experienced by many TNOCs (Muniruzzaman, 2009). The legal mechanisms will be elaborated in turn below.

\subsection{The Legal Regime}

The legal regime (in terms of the rule of law) to protect the interest of TNOC appears to be an evolving one. The fact that the rule of law is often associated with changing geo-political environment. The rule of law that may be relevant for the protection of TNOCs can be discussed under the three protective layers of rules: (i) national legislation including stability agreements; (ii) investment agreements between the parties; and (iii) bilateral and multilateral 
treaties between the TNOC's home stage government and the host oil- endowed nation where the investment is made (Maniruzzaman, 2007).

Most specifically, the protection of TNOCs may be provided in relevant national legislation such as investment codes, specific legislation on investment and stability laws. This requires TNOCs to enter into stability agreements with the host country for the security of investment for a specific period of time, usually 10-15 years. Moreover, the investment contract between the parties could be known as production sharing contract (PSC), service contract, and management contract, etc. (Maniruzzaman, 1993).

The investment contract often provides for various clauses such as stabilization clauses, renegotiation clauses, nonnational law (e.g., international law, general principles of law, transnational law) clauses as the governing law of the contract, international arbitration clauses, provision for compensation for expropriation, nationalization or creeping expropriation / indirect taking, and clauses for waiver of immunity of the state or state enterprise from both jurisdiction and execution (Maniruzzaman, 2007). In addition to the protective regime in the host nation's legislation and the investment contract between the parties, investment treaties between the home state and the host country of the TNOCs can also act as the protective regime (Maniruzzaman, 2009). Broadly speaking, an TNOC can take following legal measures to mitigate the resource nationalism risk.

\section{Incorporation of International Law or Other Non-National Legal System}

The TNOCs can bargain with the host government to incorporate several mechanisms in the legal documents that could avert non-commercial risks. For example, international law or other non-national legal system can help manage disputes between the parties in a cycle of resource nationalism. Traditionally, the host government changes its law to ensure its economic and political gain. Against this backdrop, the incorporation of the host state's law in the contract as its governing law is thus risky. As a means of aversion of such legal risks, TNOCs can incorporate international law or such other non-national legal system, rules and principles as the governing law of its contract. It is observed that the emerging popularity seems to be the application of international law or such other non-national legal system. Such laws and rules will be treated as the controller of the host state's law based on Article 42 (1) of the ICSID Convention (Schreuer, 2001; Gaillard and Banifatemi, 2003). The purpose of providing for non-national legal systems is to take the contract out of the host government's influence. This move seems to be an effective mechanism for the aversion of risk from change in law affecting the contract, which could ensure stability in the contract regime.

\section{Encouraging Third-Party Dispute Resolution (E.G., Arbitration/Mediation)}

As a safeguard measure against the State's legislative and regulatory measures, TNOCs can incorporate the international dispute settlement clauses. The provision for international dispute settlement mechanism (e.g., arbitration or mediation) in the contract between TNOCs and the host country's government could also help protect the best interest of TNOCs (Muniruzzaman, 2009). Since the legal systems of the oil-rich countries are not well developed as in the Western world, there is strong possibility that the decision of the host government's court could be manipulated against the TNOC's interest. In this context, the provision for international dispute settlement mechanism is likely to be a safeguard of the TNOC's interest. The third party dispute settlement could be done with an international arbitral tribunal. The international arbitral tribunal might interpret the chosen host government's law in light of international law on the basis of various international elements of the contract concerned. Such initiative could come up with an acceptable decision on the dispute between TNOCs and the host country's government. For example, Conoco-Phillips have recently pursued international arbitration for compensation over seized Venezuelan assets.

Mediation is another third-party dispute resolution mechanism to settle investor-State disputes (Schwebel, 2009). Mediation has many advantages over arbitration such as cost effectiveness, confidentiality of the process, expediency and flexibility. There are disputes that could easily be resolved by way of mediation in order to defuse tensions between the parties involved (Wälde, 2006). In the fresh wave of resource nationalism, this mechanism could operate as a safeguard mechanism in time of need and urgency.

Furthermore, there can also be a combination of mediation and arbitration in the same proceeding. There is already a plethora of literature on the modus operandi of the combination of arbitration and mediation (Muniruzzaman, 2003). 
In certain contexts, the combinations of these methods may be helpful. Both mechanisms could operate as a twin tool for risk as well as dispute management. However, the success of such combined tool depends on the nature of disputes.

\section{Incorporation of Stabilization Clause}

Another strategy in respect to legal regime is the incorporation of stabilization clauses as a safeguard measure against the State's legislative and regulatory measures. The stabilization clauses in a contract bear legal significance especially for higher amount of compensation than in the case where the clause is absent. The TNOCs can incorporate stabilization clauses in their contracts with the host government (Muniruzzaman, 2005; 2008). This is mainly to tackle political risk factors.

Looking at the development of stabilization practices over the last four decades, such clauses may be discussed under as classic stabilization clauses and modern stabilization clauses (Muniruzzaman, 2009). The classic stabilization clauses aim at prohibiting the exercise of the State's sovereign authority to interfere with the TNOC's interests by legislative or regulatory means. On the other hand, the modern stabilization clauses attempt a balance between the State's authority to exercise its sovereign power and the contracting TNOC's interest. The modern stabilization clauses guarantee that the State's exercise of the sovereign authority does not disturb the original balance of the contract agreed between the parties at the time of the execution of the contract. Rather the State authorities should maintain the original balance at all times during the lifetime of the contract by way of a predetermined formula.

Hence, it will be obligatory duty of the State's part to pay compensation for the financial loss incurred by the TNOC concerned, or to negotiate with the TNOC concerned in good faith to do so (Muniruzzaman, 2009). There can also be provision that the third-party dispute settlement mechanism, i.e. arbitration. Arbitration could be used in case of the parties' failure to reach an agreement on to how the equilibrium of the contract has to be rebalanced.

In the height of resource nationalism, these mechanisms could be even valuable as a pressure mechanism, which could prove deterrent against the host State's harmful actions against TNOCs. Many companies are keen to clinging to their fate whatever the circumstances, and the rule of law shied away for the time being. As noted earlier, Conoco-Phillips and ExxonMobil declined to bow down to the demands of the Venezuelan government. Rather they went on to invoke the rule of law. ExxonMobil won court orders to freeze up to $\$ 12$ billion of Venezuela's global assets, which is branded as "the boldest response yet against the resource nationalism" in the current cycle, which could be an inspiration for many other TNOCs that shied away (Muniruzzaman, 2009). Although the TNOCs could threaten legal actions against the governments to resist state intervention as done by Conoco-Phillips and ExxonMobil, however, they may risk losing access to oil resources if they upset the oil- endowed nations. (Petroleum Intelligence Weekly, 2007). Against this backdrop, there can be various geo-political factors where the use of legal weaponry may prove riskier than the non-use of it (Muniruzzaman, 2009). These geo-political factors under the political regime will be elaborated next.

\subsection{The Political Regime}

Resource nationalism is legal as a manifestation of the sovereign authority of the oil-rich country. But the method or the way in which such policy is exercised could be questionable. The TNOCs could better manage such a risk using political regime in order to maintain super profits. The political regime can play a role to defuse tensions between the parties involved in the oil industry.

Since resource nationalism policy seems to stay in resource-rich countries, TNOCs have no choice but to accept the sovereign right of resource-endowed countries to establish a stronger participation in the oil industry. Apart from the legal tools for the management of resource nationalism risks as mentioned in the previous section, there are also political tools that can be used to manage risk and dispute. In stressing the importance of managing the risks of resource nationalism, TNOCs can give special attention to more participation of host government's in equity. Among the political mechanisms, one may mention the following: 
Introduction of a Progressive Taxation System

Progressive taxation system is worth considering for the purpose of the resource nationalism risk management and dispute avoidance. As noted earlier, the unilateral actions of oil-rich nations' government to increase its income in the wake of increasing oil prices are taken as violating stabilization clause. Although stabilization clause seems to prohibit host government to do so, the automatic solution for an TNOC to such situation is the introduction of a progressive taxation system. Such a system can operate as an in-built fiscal mechanism without brining the parties to a petroleum contract to renegotiate the deal.

For the long-term stability of the contractual relationship between a State and a TNOC, the progressive taxation system is proved to be a very useful tool (Muniruzzaman, 2009). This can save the time and troubles of the parties for renegotiation. The progressive taxation system can operate on the basis of a predetermined equation and not as a surprise imposed by the government unilaterally. As originally developed in the mining industry, the progressive taxation system has been evolved to provide an automatic adjustment of the increased profitability of the project to the host country's share. It is not a substitute for income tax. Rather it is an additional payment to the government based on the extra profits earned by the TNOCs. The main advantage of this progressive taxation system is the stability of the parties' contractual relationship as the State party does not need to take any unilateral action to increase its take when windfall profits accrue. It gives the fiscal regime the needed flexibility in changed circumstances.

\section{Allowing the Host Government (and it's NOCs) Participation in the Stake}

TNOCs can preserve their long-term interests by allowing host government or its NOCs to take part in ownership in the stake, and thereby share profits accordingly. Equity participation in an oil project with an oil-rich country is worth considering for the purpose of risk management and dispute avoidance (Stevens, 2009). In the wave of resource nationalism, the host country's ownership in the oil project can act as a shield against the unilateral action by the host government. Since the host government concerned has some interest at the stake it will try to guard the business of joint ownership by all means. If it fails to do so, the government will be confronted with political risk of its own fate (Muniruzzaman, 2009).

\section{Hedging Against Political Risk Through Insurance}

Political risk is probably more obvious in the oil industry than in any other sector (Click and Weiner, 2010). TNOCs' investment in oil-rich countries is always prone to political risk. The TNOCs can take out insurance coverage to avert political risks such as breach of contract, the expropriation of property, currency inconvertibility and political violence, etc (DeLeonardo, 2005). To hedge against political risk, there are various international agencies, such as the US Overseas Private Investment Corporation (OPIC), the World Bank's Multilateral Investment Guarantee Agency (MIGA), and Export Credit Agencies (ECAs), and private insurers such as the American International Group, Lloyds of London, Sovereign Risk Insurance Limited, Chubb and Zurich Emerging Markets Solutions (Muniruzzaman, 2009).

In addition to the government sponsored agencies and private insurers that offer insurance against political risks, the TNOCs can take political risk coverage including CEND (Confiscation, Expropriation, Nationalization and Deprivation) risks, Forced Abandonment and Selective Discrimination, terrorism and political violence from the private insurance companies.

\section{Involving International Financial Institutions}

Another strategy within the political regime is to involve international financial institutions in the activities of TNOCs in oil-rich countries to safeguard against resource nationalism. The international financial institutions such as the World Bank (WB), International Monetary Fund (IMF), the Asian Development Bank, African Development Bank, and similar other institutions can be engaged, as deemed appropriate, as guarantor, lender or investor in the project concerned (Muniruzzaman, 2009). 
The World Bank and other regional developmental banks have an influence on developing countries, which often rely on such financial agencies for the financing of their development programmes. It may happen that the resource nationalism of an oil-endowed country may upset these institutions, which may have affected on the development aid that it receives. The financial institutions' involvement can help manage and minimize political risk as a host government will think twice before inflicting any injury to an TNOC as it might jeopardize the project which, in turn, could upset the influential financial institutions involved. Having discussed the political regime in terms of resource nationalism risk, the social mechanisms will be focused next.

\title{
6.3 The Social Regime
}

It has to be acknowledged that the rule of law cannot always be a perfect protective shield in a crisis situation. In the current geo-political contexts, the TNOCs need to show an understanding of local historical, cultural and social dynamics. In order to resolve disputes over resource nationalism, TNOCs can come up with robust responsible and sustainable programs as a way to reduce perceived injustices over profit sharing. Apart from the legal and political tools for the management of resource nationalism risks as mentioned earlier, there can also be social regime that can be used to manage risk and dispute. Among the social mechanisms one may mention the following:

\section{Engaging in Local Social Activities}

The TNOCs has corporate responsibility to deliver to the society in which they operate. This may, in practice, also mitigate the risk of resource nationalism. The TNOCs need to consider the social consequences of economic actions, particularly social, health and human rights issues, when making business decisions. In this regard, Corporate Social Responsibility (CSR) is worth considering for the purpose of risk management and dispute avoidance. Corporate Social Responsibility (CSR) is a business opportunity as well as a business strategy rather than a business cost or burden (Porter and Kramer, 2006). The TNOCs should be willing to embrace its wider CSR initiatives through its contribution to local healthcare, education, and employment. With this aim in mind, the TNOCs can create a social fund from oil revenues so as to divert into poverty, education, environment, and economic projects. TNOCs' meaningful engagement with the host society may provide an opportunity to develop much needed mutual trust and long-term co-operation between them (Sachs, 2007). These aspects could be factored into TNOC's CSR programme, which could, in turn, be used as a risk management as well as dispute avoidance tool (Kytle and Ruggie, 2005). CSR is now the reality that facing TNOCs. CSR is more important than ever for the OICs' survival and image. They need to embrace the principles of CSR. As Schwab (2008) puts it:

\begin{abstract}
"The notion of corporate social responsibility involves how a corporation responds to the expectations of its stakeholders - the wide community of all the organizations and individuals that are in any way affected by or interested in its actions: shareholders, owners, investors, employees, suppliers, clients, consumers - while trying to increase the company's value. Corporate social responsibility means addressing the wider financial, environmental, and social impact of all that a company does. It entails minimizing the negative effects of the actions of a company and maximizing the positive ones on stakeholders as well as on the communities in which the enterprise operates and the governments with which it must work."
\end{abstract}

Hence TNOCs have to pay an active role in promoting pro-CSR initiatives. They should make increasing contributions to direct investment in social projects in localities. They should involve local communities in the determination and evaluation of socio economic development projects. For example, noticing the lack of clean water, British Petroleum built two desalination plants to provide drinking water and distributed containers to the local people near the desert town of Salah in Algeria where they developed gas fields. Additionally, TNOCs have to become much more mindful of the importance of good public relations. Parallel to this, Wells and Ahmed (2007) argue that ultimate security for TNOCs lies in how a particular oil project is perceived by its host government, the local press, labor union, and nongovernmental organizations. They can communicate effectively to the local community about the contributions they are making and the benefits their investment is bringing to the host state. The TNOCs' meaningfully engagement with society can help to gain any reputation and make any impression on society for their long-term interest. 


\section{Ensuring Good Practice of Corporate Governance}

Corporate social responsibility is more than just showcase philanthropy, public relations and glossy CSR reporting. It encompasses several issues including business ethics, corporate citizenship and corporate governance. Corporate governance in particular is a critical aspect of CSR, focusing on how the responsibility of business is workout out in relation to internal and external stakeholders. The practice of corporate governance can ensure the protection of the interests of the concerned stakeholders (i.e., the host government, the shareholders, the host community, NGOs, etc.). At the same time, it may be a boon for the security of TNOCs' investment. Many of the misunderstandings between TNOCs and their stakeholders arise due to the lack of transparency process in terms of the TNOCs' operations in the host country. The TNOCs need to forge transparent relationships with host governments.

In an age of rising shareholder activism and engagement fuelled by the global financial crises, corporate governance can prevent disputes among various stakeholders (Richardson, 2008; Reid and Toffel, 2008). Various forms of transparency have been suggested by scholars (e.g., Muniruzzaman, 2009; Reid and Toffel, 2009; Sachs, 2007). The TNOCs should incorporate representatives of various stakeholders in the project planning, decision-making and negotiating processes (Muniruzzaman, 2009). In this regard, Sachs (2007) suggests that all contractual terms and all payments between host country and the TNOCs should be fully disclosed. Resonating with this view, Reid and Toffel (2009) contend that:

"Proponents of corporate environmental and social transparency argue that voluntary disclosure of corporate practices is an important step towards greater corporate engagement with stakeholders and more democratic corporate governance."

The good practice of corporate governance will help to enhance fair dealings between TNOCs and corporate stakeholders, and act as an effective mechanism for resource nationalism risk avoidance.

\section{Maintaining Good Relation with Host Government}

There has been cyclical change in the relative balance of power between host states and their NOCs and major TNOCs (Stevens, 2008). TNOCs seem to jeopardize their future growth if they fail to work with host governments towards their mutual best interests. The TNOCs should be aware of the importance of continuous engagement with host government as a protection measure.

The TNOCs should not upset host governments in getting preferential treatment from the oil-rich nations. If the TNOCs cooperate with governments in social works, there is possibility that the major TNOCs will secure favorable deals in future. In other words, if the TNOCs continue to foster good relations with host governments, this will help TNOCs to get preferential treatment and greater scope for negotiation of the terms of any new requirements affecting their investment in the oil-rich nations. Resonating with this, Zahraa and Shehu (2006) argue that many TNOCs are now-a-days making an effort to engage meaningfully with the host government in different degrees for a better relationship for their future prospect. In some cases, it may be advisable to TNOCs to accept even revised terms if this helps sustain relationships of the host governments, which hopefully protect their investments.

\section{Administering Early Detection of Grievances}

In the case of oil projects there should be mechanisms in place that would work like radar for early detection of grievances of the host countries. The early detection can help TNOCs to design prevention mechanisms, which eventually mitigate risk of resource nationalism. In this respect, TNOCs need to be proactive and understand the cultural milieu in which they operate (Muniruzzaman, 2009). Every dispute has a gestation period to evolve, or there may be an abrupt outbreak. Whatever is the nature of grievances or disputes, early detection of a dispute could be a blessing for TNOCs in terms of saving their valuable time which could be wasted away in arbitration or litigation processes. The overall outcome for the parties concerned in the early detection process will be a 'win-win' situation. For example, Shell's use of scenario analysis offers a deeper understanding of global developments in oil industry in terms of the world's supply, use and needs. Shell's pioneering use of scenario planning helped to envision proactive strategies in the wake of unimaginable 1973 oil event. 
The TNOCs can administer regular survey with the help of local NGOs to identify grievances or disputes of other stakeholders, particularly the local community. The possible results of the survey can act as early detection mechanism so that the TNOCs can determine what to do in the emerging situation. Efforts must be made to resolve any problem amicably between the parties involved before it escalates into a dispute.

\section{CONCLUSION}

The resource nationalism policy has seen as a weapon for the oil-rich countries to ensure the increasing control of their oil resources from TNOCs. The varied reasons for the resource nationalism in petroleum industry have triggered market and policy responses in the oil-endowed nations. Most specifically, oil price volatility underpinned by demand growth leads the new wave of resource nationalism. The continuing high price for oil has made resource nationalism more attractive to oil-rich nations around the world. That is, the oil price boom of recent years has made TNOCs a prime target for host governments to raise revenues. However, oil prices become a two-edged sword for the TNOCs. Due to resource nationalism, these companies face a difficult dilemma. Whereas the "seven sisters" used to control well over half of the world's oil production, now the produce just $10 \%$ percent. Other factors that caused resource nationalism include the robust demand creating in the emerging countries, the increasing power of NOCs, and the emergence of nationalist government.

The notion of resource nationalism has been witnessing in many different forms. It has become a common practice among host governments to seek a greater share of the profits through measures like taxes, royalties and increased domestic participation in projects. Without a doubt, such a policy is a legitimate right for sovereign nations. However, all of the forms of resource nationalism mentioned are threatening for major TNOCs- Exxon Mobil, Royal Dutch Shell, BP, Chevron, ConocoPhillips, Total and Eni. In the contemporary socio-political scenario, the TNOCs have been unsuccessful in bargaining with other major actors, such oil rich countries' government, oil importing countries' government, and NOCs. NOCs backed by their government are taking various moves to impede TNOCs from obtaining access to their oil resources. In fact, the debate over resource nationalism severely limits areas open to TNOC investment and has had negative effects on their operations.

Resource nationalism has come to stay in resource-rich countries. The recent wave of resource nationalism leads to various disputes between the oil-rich countries and TNOCs. In response, TNOCs have no choice but to surrender to the sovereign right of resource-endowed countries to establish a stronger participation in the oil industry. Against this backdrop, the TNOCs have to effectively address serious issues that caused by the resurgence in resource nationalism in the oil sector. The ways in which the major TNOCs respond to the resource nationalism in oil industry are the prime focus of this paper.

The strategy of TNOCs should be to develop and maintain some risk management tools that could be effective to avert or to manage the resource nationalism risk. They should be more sensitive in their approach in dealing with oilendowed countries' governments. As will be apparent, TNOCs could think of a strategy well in advance before entering into a relationship with the host government. This will help them manage disputes with the host government in a cycle of resource nationalism or any other time when the host government is in a stronger bargaining position.

The paper prescribes the mechanisms that TNOCs should develop to mitigate resource nationalism risk with respect to legal, political and social regimes. These measures seem to contribute to the dispute management and avoidance, and help the parties to continue their relationship with less hassle. The TNOCs have to take the political and social considerations more than using legal measures.

It is time to reshape the TNOC's behavior and activities in the wave of resource nationalism for their survival. TNOCs should also look forward to novel and exciting opportunities, emphasizing those parts of their business where they do better than NOCs - research and innovation (Stanislaw, 2008). Hence, the TNOCs should find other alternative energy rather than focusing exclusively on fossil fuels. In this regard, British Petroleum abbreviates its name to BP and announces that it stands for "beyond petroleum". The TNOCs should allocate billion dollar for research and development (R\&D) investment in alternative and renewable fuels. For example, clean renewable processes (e.g., wind and solar energy) are environmentally sustainable and ethically sound. They can form strategic alliances with research-based universities. In the meantime, British Petroleum has spent $\$ 8$ billion for R\&D in alternative and 
renewable fuels and agreed to spend half a billion dollars to create the Energy Biosciences Institute at University of California at Berkeley to study bio-fuels. Similarly, Chevron recently formed an alliance with a Silicon Valley startup to produce fuel from algae (Buchanan and Anwar, 2009).

The strategy of TNOCs mentioned in this paper will help to effectively tackle the resource nationalism risk. The paper suggests the major TNOCs to come up with robust responsible and sustainable programs so as to reduce perceived injustices over profit sharing. The paper provides a useful reference point for researchers who wish to study empirically the perception of the TNOC managers on resource nationalism and risk avoidance tools. However, the paper ignores other resources such as mining and other mineral resources in its discussion. Furthermore, it did not take into account host governments' perspective in resource nationalism. Future research may incorporate other sectors of resources industry from various stakeholders' (e.g., government) perspective to get a holistic picture of the cause and effect of resource nationalism.

\section{AUTHOR BIOGRAPHIES}

Professor Sajjad M. Jasimuddin (Corresponding author), Professor of International Business Strategy, Kedge Business School, Domiane de Luminy BP 921, 13288 Marseille cedex 9, France. Email address: sajjad.jasimuddin@kedgebs.com

Professor A F M (Munir) Maniruzzaman, Professor of International Law, School of Law, Richmond Building Portland Road Portsmouth PO1 3DE, University, UK. Email: munir.muniruzzaman@port.ac.uk

\section{REFERENCES}

Blindheim, B. (2008). Corporate social responsibility: The economic and institutional responsibility of business in society. in A. Mikkelsen \& O. Langhelle (eds.), Arctic Oil and Gas: Sustainability at Risk, London: Routledge.

Buchanan, F. R. \& Anwar, S. T. (2009). Resource nationalism and the changing business model for global oil, Journal World Investment \& Trade 10, 241.

Bremmer, I. (2008). The return of state capitalism. Survival, 50(3), 55-64.

Bremmer, I. \& Johnston, R. (2009). The rise and fall of resource nationalism. Survival, 51(2), 149-158.

Click, R. W. \& Weiner, R. J. (2010). Resource nationalism meets the market: Political risk and the value of petroleum reserves. Journal of International Business Studies, 41, 783-803.

Domjan, P. \& Stone, M. (2010). A comparative study of resource nationalism in Russia and Kazakhstan 2004-2008, 62, EuropeAsia Studies, 38.

EIA (2010). International Energy Statistics. U.S. Energy Information Administration, Available at http://www.eia.gov/cfapps/ipdb project

Economist (2006). Really big oil, Vol 380 (issue 8490), 8 December p. 11.

Ernst \& Young (2011). Business risks facing mining and metals 2011-2012. Ernst and Young, London: UK.

Gaillard, E \& Banifatemi, Y. (2003). The meaning of "and" in Article 42(1), Second sentence, of the Washington ConventionL The role of international law in ICSIS choice of law processes, 18 ICSID Rev-FILJ (2003), p. 375.

Guriev, S., Anton, K., \& Konstantin, S. (2008). Determinants of expropriation in the oil sector: A theory and evidence from panel data CEPR Discussion Paper 6755.

Hartley, P. Kanneth, B. \& Medlock III, (2007). A model of the operation and development of a national oil company. James A. Baker III Institute for Public Policy, Rice University.

Herberg, M. E. (2011) Introduction: Asia's Rising Energy and Resource Nationalism, NBR special report \#31, The National Bureau of Asian Research.

Hughes, L. \& Kreyling, S.J. (2010)). Understanding resource Nationalism in the $21^{\text {st }}$ century, Journal of Energy Security July.

Intelligence Weekly (2007). Sparks fly over soaring project costs. 1 January: 5.

Jaffe, A. M. \& Lewis, S.W. (2007). Beijing's oil diplomacy. Survival, 44(1), 115-134.

Kalyuzhnova, Y. \& Nygaard, C. (2009). Resource nationalism and credit growth in FSU countries. Energy Policy, 37, 47004710 .

Kretzschmar, G. L., Kirchner, A. \& Sharfzynova, L. (2010). Resource nationalism- Limits to foreign direct investment. The Energy Journal, 31(2), 43-68.

Kytle, B. \& Ruggie, J. G. (2005). Corporate social responsibility as risk management: A model for multinationals (March 2005), Working Paper No. 10 of the Corporate Social Responsibility Initiative of the John F. Kennedy School of Government, Boston: Harvard University.

Maloney, S. (2008). The gulf's renewed oil wealth: Getting it right this time? Survival, 50(6), 129-150.

Maniruzzaman, A F M. (2009). The issue of resource nationalism: Risk engineering and dispute management in the oil and gas 
industry. Texas Journal of Oil, Gas and Energy Law, 5(1), 79-108.

Maniruzzaman, A. F. M. (1993). New generation of natural resource development agreements: Some reflections. Journal of Energy and Natural Resources Law, 11(4), 207-247.

Maniruzzaman, A F M. (2007). National stability laws for protection of foreign investment: A Comparative perspective. Journal of World Investment \& Trade (April 2007), p.1.

Maniruzzaman, A. F. M. (2003). The problems and challenges facing settlement of international energy disputes by ADR methods in Asia: The way forward. International Energy Law and Taxation Review, 6, June, p. 193;.

Maniruzzaman, A. F. M. (2008). The pursuit of stability in international energy investment contracts: A critical appraisal of the emerging trends. Journal of World Energy Law and Business 1(2), 121-157.

Maniruzzaman, A. F. M. (2005). Some reflections on stabilization techniques in international petroleum, gas and mineral contracts. International Energy Law and Taxation Review, April, 96-100.

Mares, D.R. (2011). Oil policy reform in resource nationalist states: Lessons for Mexico. James A. Baker III, Oxford University Press.

McCracken, R. (Editor, Platts Energy Economist) TNOCs, NOCs, Facing Off Over Scarcer Resources (available at : http://www.platts.com/Magazines/Insight/2006/december/qS2006t12l07m1m126sP33_1.xml

Partlett, W. (2010). Enforcing oil and gas contracts without courts: Reputational constraints on resource nationalism in Russia and Azerbaijan, Demokratizatsiya: Journal of Post-Soviet Democratization, Winter 74-93.

PCF Energy (2007). Title! http://www.npc.org

Petroleum Intelligence Weekly, (2007).

Porter, M.E. \& Kramer, M.R. (2006). Strategy and society: The link between competitive advantage and corporate social responsibility, Harvard Business Review, December, 78-92.

Richardson, B. J. (2008). Socially Responsible Investment Law: Regulating the Unseen Polluters, Oxford: Oxford University Press.

Reid, E. M., \& Toffel, M. W. (2009). Responding to public and private politics: Corporate disclosure of climate change strategies. Strategic Management Journal, 30(11), 1157-1178.

Sachs, J. D. (2007). Addressing Political Risk in the Energy Sector, in World Investment Prospects to 2011: Foreign Direct Investment and the Challenge of Political Risk, Economist Intelligence Unit, The Economist, p.80.

Schreuer, C. (2001). The ICSID Convention: A Commentary CUP.

Schwab, K. (2008). Global Corporate Citizenship: Working With Governments and Civil Society, 87 Foreign Affairs (January / February 2008), p.107, at p.113.

Schwebel, S. M. (2009). Is Mediation of Foreign Investment Disputes Plausible”, 6 Transnational Dispute Management, 1, 2009): www.transnational-dispute-management.com

Sarsenbayev, K. (2011). Kazakhastan petroleum industry 2008-2010: Trends of resource nationalism policy? . Journal of World Energy Law and Business, 4(4), 369-379.

Sikri, R. (2010). Resource competition, nationalism and their security implications. South Asia Survey, 17(1), 7-17.

Stanislaw, J. A. (2008). Power play: Resource nationalism, the global scramble for energy, and the need for mutual interdependence. Deloitte, Development LLC.

Stevens, P. (2008). National oil companies and international oil companies in the Middle East: Under the shadow of government and the resource nationalism cycle. Journal of World Energy Law and Business 1(1), 5-30.

van der Linde, C. (2000). The State and the International Oil Market: Competition and the Changing ownership of Crude Oil Assets. Boston, MA: Kluwer Academic Publishers.

Vernon, R. (1971). Sovereignty at Bay: The Multinational Spread of US Enterprises. New York: Basic Books.

Vivoda, V. (2009). Resource nationalism, bargaining and international oil companies: Challenges and change in the new millennium. New Political Economy, 14(4), 517-534.

Wälde, T. W. (2006). Efficient management of transnational disputes: Mutual gain by mediation or joint loss in litigation 22 Arbitration International l., p.205.

Ward, H. (2009). Resource nationalism and sustainable development: A primer and key issues. Working Paper, London: the International Institute for Environment and Development (IIED).

Webber, J. \& Johnson, M. (2012). Argentina to seize oil group. Financial Times, April 12, p. 1.

Wells, L. T. \& Ahmed, R. (2007). Making Foreign Investment Safe: Property Rights and National Sovereignty, Oxford: Oxford University Press.

Weiner, R. J. 2005. Speculation in international crises: report form the Gulf. Journal of International Business Studies, 36(5), 576-587.

Zahraa, M. \& Shehu, A. (2006). Environmentalism versus oil nationalism in the Niger Delta: Current concerns and dilemma of the multinational oil industry, Oil, Gas \& Energy Law Intelligence Service, 4 (3), 1-29. 